\title{
THE EFFECT OF INDONESIAN VELVET BEAN EXTRACT ON THE FERTILITY OF ALBINO MALE MICE
}

\author{
RATNANINGSIH EKO SARDJONO, VIENSA PRADIPTA, IQBAL MUSTHAPA
}

\author{
Department of Chemistry Education Universitas Pendidikan Indonesia \\ Email: ratnaeko@upi.edu
}

Received: 26 Apr 2016 Revised and Accepted: 28 May 2016

\section{ABSTRACT}

Objective: This research aims to determine the dose of Indonesian velvet bean (Mucuna pruriens) extract which has significant effect on the ferlitity mice (concentration, motility and morphology of mice sperm). The extract is expected to become an alternative infertility herbal medicine relatively more secure and affordable replacing synthetic hormonal drugs which tend to have negative effects.

Methods: The seed was taken from Yogyakarta Indonesia. Fertility test was done to fertile adult male albino mice 12 w old, weighing $25-35$ grams. Fertility tests performed on seven groups of mice; i.e. negative control, positive control and treatment groups (five dose levels at $50,100,150,200$ and $250 \mathrm{mg} / \mathrm{kg}$ body weight). Subsequent fertility test results were statistically tested, including tests of normality (Kolmogorov-Sminov) followed by T test (Independent-Samples T Test).

Results: The sperm concentration and motility increased as an increased dose of seed extract was applied, as well as decreased abnormal morphology. The highest change in the quality and quantity of sperm occurred at the dose of $250 \mathrm{mg} / \mathrm{kg}$ body weight with increased sperm concentration of about 22 million, sperm motility increased by $18 \%$ and decreased abnormal sperm morphology by $12 \%$. Statistical analysis showed a significant increase in sperm concentration and motility at doses of 100, 150, 200 and $250 \mathrm{mg} / \mathrm{kg}$ body weight, whereas a significant decrease of abnormal sperm morphology was found at doses of 150,200 and $250 \mathrm{mg} / \mathrm{kg}$ body weight.

Conclusion: Based on this study it is concluded that Indonesian velvet beans seed extract can increased the fertility of albino male mice significantly at dose level $250 \mathrm{mg} / \mathrm{kg}$ body weight.

Keywords: Mucuna pruriens, L-dopa, Sperm Concentration, Sperm Motility, Sperm Morphology

(C) 2016 The Authors. Published by Innovare Academic Sciences Pvt Ltd. This is an open access article under the CC BY license (http://creativecommons.org/licenses/by/4.0/) DOI: http://dx.doi.org/10.22159/ijpps.2016v8s2.15223

\section{INTRODUCTION}

Modern life style and certain environmental exposure may have caused male infertility [1]. Various factors can directly or indirectly lead to this sexual disfunction [2-5]. These days, the number of male with infertility problem keeps increasing across the world. Various types of modern medicine have been applied to solve this problem but many of which yield negative effects $[6,7]$

Infertility problem has been a global issue [8]. Various studies had been done to investigate whether there is a reduction of quality in men's fertility in the last $40 \mathrm{y}$ [9]. Many researches proved that there is a drop of density in human sperm. A study comparing the quality of male fertility in 1977 and 1994 in Belgium shows an 11.8\% increase of sperm abnormality and a $20 \%$ decrease of sperm motility. It was also found out that males born prior to 1970 s have $25 \%$ lower amount of sperm compared to those born before 1950s [10]. A review study showed a significant decrease in mean sperm count from $113 \times 10^{6} / \mathrm{ml}$ in 1940 to $66 \times 10^{6} / \mathrm{ml}$ in 1990 [11]. In Australia, 1 out of 20 males has infertility problem and $50 \%$ of all infertility problems are associated with male [12]. In Indonesia, the number of infertility increases by $15-20 \%$ of 50 million couples. This infertility is consecutively caused by male (40\%) and female $(40 \%), 10 \%$ of both male and female, and another $10 \%$ of unidentified reasons [11]

Various researches have been conducted to restore male infertility [13-15]. Some endocrinal substances such as cytomel thyroid, glucocorticoid, androgen, mesterolone, gonadotropin, and clomiphene citrate of low dose have been tested to restore male fertility. In addition to these endocrinal substances, many types of herbal medicine have also been used to reinstate this fertility problem. Believed to have relatively lower negative side effects, herbal is more preferable than synthetic medicine [16-18].

One potential plant to solve this fertility problem is velvet beans (Mucuna pruriens) [19]. It has been identified that velvet bean can regulate steroidogenesis and improve the quality of infertile male sperm [20]. The extract of velvet beans is known to be able to increase the quantity and motility of male mice sperm and decrease its abnormal morphology. This extract can affect the morphology of male mice reproduction organ; testis and epididymis. The testis of a male mouse which has been given velvet bean extract is known to have increased tubular diameter and spermatoid quantity [21].

L-Dopa is an important component of velvet beans [22]. As previously studied, L-dopa and other substances found in velvet beans have been proven effective in improving the sexual performance of albino male mice [23]. It is also reported that L-dopa can increase libido and thus improve sexual behaviour [24].

The content of L-dopa in velvet beans may be varying depending on the origin and environmental conditions. The Indonesian velvet beans, especially originating from Bantul district, have L-dopa content of $7.56 \%$ [25]. Despite the numerous studies on the ability of L dopa in velvet beans in increasing the fertility of men, however L-dopa in velvet beans from Indonesia has not been well investigated on their ability in increasing the fertility of men, as well as the dose which give the significant effect. The recent study is conducted to provide a more comprehensive understanding of the effect of Indonesia velvet beans extract on the fertility of male albino mice (Mus musculus), especially on the concentration, motility, and morphology of sperm.

\section{MATERIALS AND METHODS}

\section{Material}

Sample or material used in this research is the seed of velvet beans (Mucuna pruriens) which originates from Yogyakarta Indonesia, whereas animals were obtained from the Laboratorium of Biotechnology of Institut Teknologi Bandung (ITB).

\section{Sample preparation}

The chosen velvet beans were cleaned, peeled, dried up, and then mashed using a grilling machine. The velvet bean powder was then 
extracted using the maceration method $(3 \times 24$ h) with water and ethanol (1:1) as the solvent and citric acid added until the $\mathrm{pH}$ reached 3 in room temperature. Every $24 \mathrm{~h}$, the samples were filtered and remacerated. The addition of citric acid was done to increase the solubility of the main compound in velvet bean, L-dopa. The solvent in the velvet bean macerate was then evaporated using the rotary vacuum evaporator. The evaporated macerate was then dried up using the freeze dryer, resulting brown-black dry velvet bean extract in $1.58 \%$.

\section{Determining the level of L-dopa}

The percentage of L-dopa identified uses high-performance liquid chromatography (HPLC) analysis [26]. This step started with making a standard solution of L-dopa with concentrations $25,50,75,100$ and $125 \mathrm{ppm}$. The velvet bean extract was tested using HPLC with a testing parameter of $\lambda=280 \mathrm{~nm}$, speed flow $1 \mathrm{ml} /$ minute and solvent ratio of $\mathrm{H}_{2} \mathrm{O}$ : Methanol: $\mathrm{H}_{3} \mathrm{PO}_{4}$, that is 97:20:1 [27].

\section{Animal treatments}

In this study, 45 male mice ( $12 \mathrm{w}$ old) weighing about $25-30$ g were used for the investigation. The mice were acclimatized to an average temperature of $23-29{ }^{\circ} \mathrm{C}$ for seven days so that these tested animals could adapt themselves to their new environment during the treatment. They were grouped into cages of $30 \times 20 \times 12 \mathrm{~cm}^{3}$ based on treatment with the five mice per cage. During the acclimatization period, these animals were fed following PC551 standard and water ad libitum.

All the animals were divided into seven groups of five each and treated as follows. Group I: negative control; group II: positive control (L-dopa treatments, $50 \mathrm{mg} / \mathrm{kg}$ ), group III-VI: administration of velvet beans extract $(50,100,150,200,250 \mathrm{mg} / \mathrm{kg})$. Velvet beans extract was administered for $30 \mathrm{~d}$, through oral intake, once per morning. Each mouse of treatment group received certain doses of velvet beans extract whereas that in the positive control group was given pure Ldopa of dose $50 \mathrm{mg} / \mathrm{kg}$ body weight. The amount of velvet beans extract given was $0.3 \mathrm{ml} /$ day for each concentration.

\section{Assesments the sperm concentration [28]}

Neck-dislocated died mice were located on a tray for surgery. Their cauda epididymis was isolated using phosfate buffered saline (PBS). Sperm liquid was emptied from cauda epididymis by a syringe before it was dissolved with $2 \mathrm{ml}$ PBS until it became homogenous.

Sperm suspension was emptied by a leukocyte pipet until 1.0. The sperm suspension containing pipet was the dissolved by PBS until 1.1 before it was well shaked. The calculation of sperm concentration used haemocytometer improved neubauer before it was observed by a microscope of 400x magnifications. The calculation was conducted for five boxes of counting chamber (a total of 25 boxes) for each sample, prior to average calculation. The result of calculation is the sperm concentration in $10^{-5} \mathrm{ml}$ sperm suspension (sperm concentration $/ \mathrm{ml}=25 / 5 \times$ dillution $\times$ sperm count average $) / \mathrm{mm}^{3}$ ).

\section{Assessment the motility of the sperm [28]}

Sperm motility was observable from sperm suspension dropped on neubauer counting chamber observed by a microscope of $400 \mathrm{x}$ magnifications. Sperm motility is valued on the basis of percentage of good sperm motility, that is, the sperm which moves fast, straight forward and active.

\section{Assesment the morphology of the sperm [28]}

Sperm morphology is observable with colouring eosin Y 1\%. Sperm morphology testing was conducted by differentiating the shape of normal and abnormal sperm of 100 sperms observed before it was made into a percentage. Abnormal sperm includes abnormality such as broken, detached and thin head; broken, crooked and droplet cytoplasm middle part; or broken, crooked and coil tail. The observation used a microscope of 400x magnifications.

\section{Analysis of the data}

Results are expressed as mean $\pm \mathrm{SD}$ for 5 animals per group. The normality of the data acquired was then tested using the test of normality (Kolmogorov-Sminov). Normally distributed data can be analysed using the T test (Independent-Samples T Test). The Software SPSS 20 was used for the analysis.

\section{RESULTS}

\section{The level of L-dopa}

The chromatogram of HPLC indicates that the peak standard L-dopa appears at the retention time (RT) of 3.44. The seed extract chromatogram shows seven peaks at different retention period. Having been compared to standard calibration curve, the obtained data show that percentage of L-dopa in the Indonesian velvet bean extract was $13.9 \%$.

The effect of the velvet bean extracts on sperm concentration, motility, and morphology

Mice sperm concentration was observed on the $31^{\text {st }}$ day after the application of velvet beans extract for $30 \mathrm{~d}$. The result of this observation can be seen in table 1 .

Table 1: The experimental results of mice sperm concentration

\begin{tabular}{lll}
\hline Mice groups (n=5) & Treatments & Mice sperm concentration $(\mathbf{x 1 0} / \mathbf{m l})$ \\
\hline I & Negative control & $34.8 \pm 3.19$ \\
II & Positive control & $37.2 \pm 3.25$ \\
III & Treatment group $(50 \mathrm{mg} / \mathrm{kg}$ body weight) & $39.4 \pm 4.00$ \\
IV & Treatment group $(100 \mathrm{mg} / \mathrm{kg}$ body weight) & $41.9 \pm 1.43^{*}$ \\
V & Treatment group $(150 \mathrm{mg} / \mathrm{kg}$ body weight) & $43.6 \pm 1.91^{*}$ \\
VI & Treatment group $(200 \mathrm{mg} / \mathrm{kg}$ body weight) & $49.5 \pm 1.22^{*}$ \\
VII & Treatment group (250 mg/kg body weight) & $56.7 \pm 3.13^{*}$ \\
\hline
\end{tabular}

*) Significantly different from control $(\mathrm{p}<0,05)$

Table 2: The experimental results of mice sperm motility

\begin{tabular}{lll}
\hline Mice groups (n=5) & Treatments & Mice sperm motility (\%) \\
\hline I & Negative control & $73.8 \pm 0.83$ \\
II & Positive control & $76.0 \pm 1.58^{*}$ \\
III & Treatment Group ( $50 \mathrm{mg} / \mathrm{kg}$ body weight $)$ & $77.2 \pm 1.92^{*}$ \\
IV & Treatment Group $(100 \mathrm{mg} / \mathrm{kg}$ body weight $)$ & $78.4 \pm 2.07^{*}$ \\
V & Treatment Group (150 mg/kg body weight) & $81.2 \pm 2.38^{*}$ \\
VI & Treatment Group (200 mg/kg body weight) & $86.8 \pm 1.92^{*}$ \\
VII & Treatment Group (250 mg/kg body weight) & $91.0 \pm 1.58^{*}$ \\
\hline
\end{tabular}

*) Significantly different from control $(p<0,05)$ 
Table 3: The experimental results of mice sperm morphology

\begin{tabular}{lll}
\hline Mice groups (n=5) & Treatments & Abnormal sperm morphology (\%) \\
\hline I & Negative control & $16.6 \pm 1.81$ \\
II & Positive control & $16.2 \pm 1.64$ \\
III & Treatment Group ( $50 \mathrm{mg} / \mathrm{kg}$ body weight) & $15.4 \pm 0.89$ \\
IV & Treatment Group (100 mg/kg body weight) & $13.0 \pm 3.31$ \\
V & Treatment Group (150 mg/kg body weight) & $11.0 \pm 1.22^{*}$ \\
VI & Treatment Group (200 mg/kg body weight) & $8.60 \pm 0.89^{*}$ \\
VII & Treatment Group (250 mg/kg body weight) & $4.60 \pm 1.34^{*}$ \\
\hline
\end{tabular}

*) Significantly different from control $(\mathrm{p}<0,05)$

Based on the data acquired, we can conclude that the velvet bean extract apparently succeeded in increasing the sperm concentration of the mice, in all dosage used in this research $(50,100,150,200$ and $250 \mathrm{mg} / \mathrm{kg}$ ). The smallest improvement happened on the $50 \mathrm{mg} / \mathrm{kg}$ dosage, while the largest improvement happened on the $250 \mathrm{mg} / \mathrm{kg}$ dosage. In general, it is observed that in the dosage range of 50-250 $\mathrm{mg} / \mathrm{kg}$, the sperm concentration and the dosage correlates positively.

The motility of the sperm was presented in table 2. Data show the use of Indonesian velvet beans extract can increase mice sperm motility in all doses.

The sperm morphology was presented in table 3 .

\section{DISCUSSION}

The experimental results showed the velvet bean extract apparently succeeded in increasing the sperm concentration of the mice, in all dosage used in this research $(50,100,150,200$ and $250 \mathrm{mg} / \mathrm{kg})$. Another interesting phenomena observed is that L-dopa was able to increase the sperm concentration of the mice, but a higher increase was observed in mice that were given the velvet bean extract. The concentration of L-dopa which was given to the positive control group was $50 \mathrm{mg} / \mathrm{kg}$, equivalent to $1.75 \mathrm{mg}$, while based on the HPLC result showed that the concentration of L-dopa in the velvet bean extract in each dosage was equivalent to $0.22,0.44,0.88,1.77$ and $3.55 \mathrm{mg}$. This fact proved that the L-dopa contained in the velvet beans was not the only one that affected the sperm concentration of the mice.

The result of the normality test showed that the sperm concentration of the mice in all seven treatments has a larger significance value than the degree of freedom 0.05 . Thus, $\mathrm{H} 0$ was accepted, which means that the data was normally distributed. Meanwhile, the result of the T-test (Independent-Samples T Test) showed that the average of sperm concentration of the positive control group and the treatment group with the $50 \mathrm{mg} / \mathrm{kg}$ dosage did not have a significant difference to the control group. However, the treatment groups that were given the $100,150,200$, or $250 \mathrm{mg} / \mathrm{kg}$ dosage showed a significant difference from the control group.

The increase in sperm concentration indicated the success in spermatogenesis process. This process is heavily affected by gonadotrophine hormones, luteinizing hormone (LH) and folliclestimulating hormone (FSH). The hormones stimulate testis, sex organ in men. Both hormones are produced by the cells in the anterior pituitary, known as gonadotrophs. The secretion of these hormones is affected by GnRH (gonadotropin releasing hormone) that is secreted by the hypothalamus. Both hormones work on different part of the testis. LH works on leydig cells to control the secretion of testosterone, while FSH works on tubulus seminiferosa, especially on sertoli cells to improve spermatogenesis.

The velvet bean extract treatment also succeeded in increasing the motility of the sperm in all dosage given $(50,100,150,200$ and 250 $\mathrm{mg} / \mathrm{kg}$ ). The lightest increase happened on the $50 \mathrm{mg} / \mathrm{kg}$ dosage, while the largest increase happened on the $250 \mathrm{mg} / \mathrm{kg}$ dosage, with the increase of about $\pm 18 \%$. In general, it is observed that in the dosage range of $50-250 \mathrm{mg} / \mathrm{kg}$, the motility of the sperm and the dosage is given correlates positively.

A living spermatozoa correlates highly to the motility of the sperm as being alive is an absolute requirement for spermatozoa to be able to produce energy and move. Semen of a mammal that has high fertility is characterized with a high level of living spermatozoa with normal morphology. Good motility depends on many things, including the morphology of the spermatozoa.

The velvet has been extract treatment succeeded in reducing morphologically abnormal sperm in all dosage given $(50,100,150$, 200 and $250 \mathrm{mg} / \mathrm{kg}$ ). The lightest reduction happened on the dosage $50 \mathrm{mg} / \mathrm{kg}$, while the largest reduction happened on the dosage 250 $\mathrm{mg} / \mathrm{kg}$ with a decrease of about $\pm 12 \%$. In general, it is observed that in the dosage range of $50-250 \mathrm{mg} / \mathrm{kg}$, the percentage of morphologically abnormal sperms and the dosage is given correlates negatively. The sperms suffered different kinds of abnormality, such as the coiled tail, curved tail, and loose head (fig. 1).

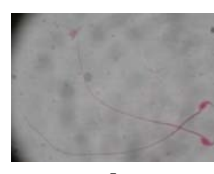

Normal sperm

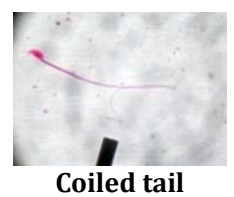

Coiled tail

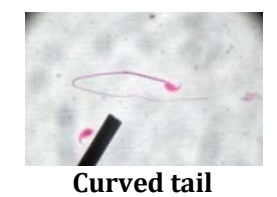

Curved tail
Fig. 1: Normal and abnormal sperm (Magnified 400x)

Sperm morphology depends on testosterone hormone secreted by Leydig cells. Disturbance in testosterone supply leads to dysfunction of the epididymis, in which spermatozoa grows [29]. Given the significant role of testosterone in spermatogenesis process, its limited supply will disturb this process and cause primary or spermatogenesis abnormalities such as over or undersized head, coiled tail, double tail and others [30].

The study shows that Indonesian velvet beans extract can increase sperm concentration and motility as well as reduce its abnormal morphology. This increase in sperm quality and quantity is inseparable from L-dopa component found in Indonesian velvet beans. This compound increase not only sexual activity but also hormones regulating spermatogenesis process such as FSH and LH.

L-dopa in human body is changed into dopamine by aromatic L-amino acid decarboxylase enzyme as a catalyst. As previously explored, psychological stress reduces dopamine and testosterone level. Increased dopamine in body can directly reduce psychological stress and stimulate brain to secrete hormone LH [31].

Increased sperm concentration and motility as well as decreased abnormal sperm morphology of mice occur because of L-dopa and other components contained in velvet beans extract which influence the secretion of testosterone. Secreted by Leydig cells, this hormone plays significantly in spermatogenesis process. The hormone belongs to steroid which is synthesized from cholesterol. The synthesis process of steroid and its derivatives is called steroidogenesis [32].

Sperm motility is an important aspect in fertilization/insemination process. A large amount of sperm is not sufficient for the insemination to take place successfully without being supported by good sperm motility. Having consumed L-dopa substance contained in velvet beans extract, the mice have increased sperm motility and level of dopamine in the brain. This dopamine stimulates the hypothalamus to secrete GnHR. Dopamine-stimulated hypothalamus increases the secretion of hormone LH and FSH [33]. Hormone FSH regulates 
spermatogenesis and nutrition needed in spermatogenesis process. Increased FSH hormone secretion improves the quality of spermatogenesis because this hormone provides all required nutrition. One benefit of increased FSH secretion is the provision of energy required by sperm to move/motile.

Sperm abnormality is caused by lack of FSH and LHin testis. Gonadotropin serum (FSH and LH) correlates with the growth of sperm morphology [34]. L-dopa contained in velvet bean is known to increase dopamine level. The dopamine can increase the secretion of FSH and LH so that they can increase the quality of sperm morphology in spermatogenesis process $[35,36]$.

\section{CONCLUSION}

The result of the fertility test showed that the Indonesian velvet bean cotyledon extract can increase the concentration and motility of sperm and reduce abnormal morphology of the sperm in mice. The change of quality and quantity in the sperm happened at the highest dosage was given, $250 \mathrm{mg} / \mathrm{kg}$. The increase in the sperm concentration was about 22 million sperms, while the increase of sperm motility was about $18 \%$, and the decrease in abnormal sperm morphology was about $12 \%$.

\section{ACKNOWLEDGEMENT}

The authors are thankful to the Indonesia Ministry of Research and Higher Education for the provision of funds and facilities for this study.

\section{CONFLICT OF INTERESTS}

We declare that we have no conflict of interest.

\section{REFERENCES}

1. Mathur M, Sundaramoorthy S. Plants with aphrodisiac potentials-the knowledge and the gaps. Indian Medicinal Plants. Jaipur: Aavishkar Publisher; 2009. p. 336.

2. Nadeem F, Fahim A, Bugti S. Effects of cigarette smoking on male fertility. Turkish J Med Sci 2012;42(Suppl 2):1400-5.

3. Oyeyipo IP, Raji Y, Emikpe BO, Bolarinwa AF. Effects of nicotine on sperm characteristics and fertility profile in adult male rats: a possible role of cessation. J Reprod Infertil 2011;12:201-7.

4. Hansen C, Luben TJ, Sacks JD, Olshan A, Jeffay S, Strader L, et al. The effect of ambient air pollution on sperm quality. Environ Health Perspec 2010;118:203-9.

5. Sheiner EK, Sheiner E, Hammel RD, Potashnik G, Carel R. Effect of occupational exposures on male fertility: a literature review. Ind Health 2003;41:55-62.

6. Hart BL. The evolution of herbal medicine: behavioral perspectives. Anim Behav 2005;70:975-89.

7. Calixto JB. Efficacy, safety, quality control, marketing and regulatory guidelines for herbal medicines (phytotherapeutic agents). Braz J Med Biol Res 2000;33:179-89.

8. Martinez G, Daniels K, Chandra A. Fertility of men and women aged 15-44 y in the United States: National survey of family growth 2006-2010. Natl Health Stat Report 2012;51:1-28.

9. Charles WC, Julian AG. Testosterone rebound therapy. Fertil Steril 1978;29:1.

10. Van KW. Deterioration of sperm quantity in young Belgian men during recent decades. Hum Reprod 1997;9:73.

11. Carlsen E, Giwercman A, Keiding N, Skakkebaek NE. Evidence for decreasing the quality of semen during past $50 \mathrm{y}$. Br Med J 1992;305:609-13.

12. McLachlan R, de Krester D. Male infertility: the case for continued research. Med J Aust 2001;174:116-7.

13. Prakash S, Prithiviraj E, Suresh S, Lakshmi NV, Ganesh MK, Anuradha $\mathrm{M}$, et al. Morphological diversity of sperm: a mini review. Iran J Reprod Med 2014;12:239-42.

14. Casas E, Vavouri T. Sperm epigenomics: challenges and opportunities. Frontiers Genetics Bioinformatics Computational Biol 2014;5:1-7.

15. Meeker JD, Rossano MG, Protas B, Diamond MP, Puscheck E, Daly D, et al. Cadmium, lead, and other metals in relation to semen quality: Human evidence for molybdenum as a male reproductive toxicant. Environ Health Perspect 2008;116:1473-9.

16. Parandin R, Yousofvand N, Ghorbani R. The enhancing effects of alcoholic extract of Nigella sativa seed on fertility potential, plasma gonadotropins and testosterone in male rats. Iran J Reprod Med 2012;10:355-62.

17. Ojo 00, Bhadauria S, Rath SK. Dose-dependent adverse effects of salinomycin on male reproductive organs and fertility in mice. PLoS One 2013;8:e69086. Doi:10.1371/journal.pone.0069086. [Article in Press]

18. Mahdi AA, Shukla KK, Ahmad MK, Rajender S, Shankhwar SN, Singh V. Withania somnifera improves semen quality in stress-related male fertility. J Evidence-Based Complementary Altern Med 2011. Doi:10.1093/ecam/ nep138. [Article in Press]

19. Shukla KK, Mahdi AA, Ahmad MK, Shankhwar SN, Rajender S, Jaiswar SP. Mucuna pruriens improves male fertility by its action on the hypothalamus-pituitary-gonadal axis. Fertil Steril 2009;92:1934-40.

20. Abraham J. Effect of mucuna purines seeds on fertility of male albino rats rattus norvegicus. J Pharm Res 2011;4:233-6.

21. Sathiyanarayanan L, Arulmozhi S. Mucuna pruriens Linn-a comprehensive review. Pharmacog Rev 2007;1:157-62.

22. Kavitha, Thangamani C. Amazing bean 'Mucuna pruriens': a comprehensive review. J Med Plants Res 2014;8:138-43.

23. Kumar AKV, Srinivasan KK, Shanbhag T, Rao SG. Aphrodisiac activity of the seeds of mucuna pruriens. Indian Drugs 1994;31:321-7.

24. Harvey NS. Serial cognitive profiles in levodopa-induced hypersexuality. Br J Psychiatry 1998;153:833-6.

25. Sardjono RE, Musthapa I, Sholihin H, Ramdhani RP. The physicochemical composition of Indonesian velvet bean (Mucuna pruriens l.). Global J Res Med Plants Indigenous 2012;1:101-8.

26. Raina AP, Khatri R. Quantitative determination of L-DOPA in seeds of Mucuna pruriens germplasm by high-performance thin layer chromatography. Indian J Pharm Sci 2011;73:459-62.

27. Misra L, Wagner $H$. Extraction of bioactive principles from Mucuna pruriens seeds. Indian J Biochem Biol 2007;44:55-60.

28. Aleissa MS. Effect of ginger supplements on some reproductive parameters and spermatogenesis of mice. J Life Sci 2014;4:271-7.

29. Robaire B, Hinton BT, Orgebin-Crist MC. Knobil and Neill's Physiology of Reproduction: The Epididymis. Atlanta: Elsevier; 2006.

30. Attia AA. Light and electron microscopic studies of the effect of alprazolam on the testicular tissue of mice. Int J Adv Res 2014;2:413-31.

31. Weinbauer GF, Luetjens CM, Simoni M, Nieschlag E. Andrology: physiology of testicular function. New York: Springer; 2010.

32. Walczak-Jedrzejowska R, Wolski JK, Slowikowska-Hilczer J. The role of oxidative stress and antioxidants in male fertility. Cent Eur J Urol 2013;66:60-7.

33. Shukla KK, Mahdi AA, Ahmad MK, Jaiswar SP, Shankwa SN, Tiwari SC. Mucuna pruriens reduces stress and improves the quality of semen in infertile men. J Evidence-Based Complementary Altern Med 2010;7:137-44.

34. Shinjo E, Shiraishi K, Matsuyama H. The effect of human chorionic gonadotropin-based hormonal therapy on intratesticular testosterone levels and spermatogonial DNA synthesis in men with non-obstructive azoospermia. Andrology 2013;1:929-35.

35. Mendis-Handagama SMLC, Siril AHB. Leydig cells, thyroid hormones, and steroidogenesis. Indian J Exp Biol 2005;43:939-62.

36. Kaphale K, Wu LS, Tsai YF. Effects of putative neurotransmitters on testosterone production from in vitro mice interstitial cells culture. J Anim Vet Adv 2003;2:119-25.

\section{How to cite this article}

- Ratnaningsih Eko Sardjono, Viensa Pradipta, Iqbal Musthapa. The effect of indonesian velvet bean extracts on the fertility of male albino mice. Int J Pharm Pharm Sci 2016;8 Suppl 2:56-59. 